\title{
HUBUNGAN ASUPAN MONOSAKARIDA, PUFA, ARGININ, ASAM GLUTAMAT DAN MASSA LEMAK TUBUH DENGAN TEKANAN DARAH PADA WANITA POST MENOPAUSE
}

\author{
Ainun Anindita Rahadyani, Adriyan Pramono*) \\ Program Studi Ilmu Gizi Fakultas Kedokteran Universitas Diponegoro \\ Jl.Dr.Sutomo No.14, Semarang, Telp (024) 8453708, Email : gizifk@undip.ac.id
}

\begin{abstract}
Background: Risk of hypertension could be increased in post menopausal woman. It is caused by the lack production of estrogen hormones. This matter also affected by some factor, such as body fat and macronutrient intake. This study was objected to observe the correlation between body fat, monosaccharide intake, arginine and glutamic acid intake, and also poly unsaturated fat intake with systole and diastole blood pressure in post menopausal woman.

Method: A cross sectional study design was conducted to 75 subjects, taken by consecutive sampling method. Intake of monosaccharide, poly unsaturated fat, arginine, and glutamic acid obtained from the semi quantitative FFQ. Bioelectrical Impedance Analyzer (BIA) been used to get the body fat data. Blood pressure was measured by an aneroid sphygmomanometer. Kolmogorov - smirnov was used as test of normality, and bivariate analysis by rank Spearman.

Result: The prevalence of systole hypertension was 17,3\%, and diastole hypertension was 37,3\%. The body fat mean was 38,2+5,39 with the $36 \%$ subject undergo obesity, while $48 \%$ subject consumed monosaccharide more than the

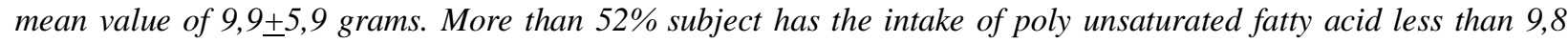
grams, arginine intake less than 3,9 grams, and glutamic acid intake less than 0,8 grams. Body fat correlated with the systole $(r=0,267 ; p=0,020)$ and diastole $(r=0,256 ; p=0,022)$ blood pressure, and monosaccharide intake with the systole $(r=0,268 ; p=0,020)$ and diastole $(r=0,291 ; p=0,011)$ blood pressure.
\end{abstract}

Conclusion: High body fat and monosaccharide intake could increase the systole and diastole blood pressure.

Keyword: monosaccharide intake; poly unsaturated fat intake; arginine intake; glutamic acid intake; body fat; blood pressure

\begin{abstract}
ABSTRAK:
Latar Belakang: Risiko hipertensi dapat meningkat pada wanita yang telah mengalami menopause, sebab berkurangnya produksi hormon estrogen. Akan tetapi hal tersebut juga dipengaruhi oleh beberapa faktor, diantaranya adalah massa lemak tubuh (MLT), dan asupan zat gizi makro. Penelitian ini bertujuan untuk mengetahui hubungan MLT, asupan monosakarida, asam amino arginin dan asam glutamat, serta asam lemak tak jenuh ganda (PUFA) terhadap tekanan darah sistolik dan diastolik pada wanita post menopause.

Metode: Desain penelitian cross sectional dengan jumlah 75 subjek diambil secara consecutive sampling. Data asupan monosakarida, lemak tak jenuh ganda, asam amino arginin, dan asam glutamat diperoleh dari FFQ Semi Kuantitatif. Data MLT diperoleh dari instrumen BIA. Tekanan darah diperoleh dari hasil pengukuran sphygmomanometer jarum. Uji kenormalan data menggunakan Kolmogorov-smirnov, analisis bivariat menggunakan rank Spearman.

Hasil: Prevalensi hipertensi sistolik yakni 17,3\%, dan hipertensi diastolik 37,3\%. Rerata massa lemak tubuh subjek sebesar 38,2+5,4 dengan 36\% subjek mengalami obesitas, serta 48\% subjek memiliki asupan monosakarida lebih dari nilai rerata sebesar 9,9+5,9 gram. Sebanyak lebih dari 52\% subjek memiliki asupan PUFA kurang dari 9,8 gram, asupan arginin kurang dari 3,9 gram, dan asupan asam glutamat kurang dari 0,8 gram. Massa lemak tubuh berhubungan dengan tekanan darah sistolik $(r=0,267 ; p=0,020)$ dan diastolik $(r=0,256 ; p=0,022)$. Asupan monosakarida juga berhubungan dengan tekanan darah sistolik $(r=0,268 ; p=0,020)$ dan diastolik $(r=0,291$; $p=0,011$ ).
\end{abstract}

Simpulan: Tingginya massa lemak tubuh dan asupan monosakarida akan meningkatkan tekanan darah sistolik dan diastolik.

Kata Kunci: Asupan monosakarida; PUFA; arginin; asam glutamat; massa lemak tubuh; tekanan darah

\section{PENDAHULUAN}

Penyakit kardiovaskuler yang dialami oleh

wanita post menopause memiliki tingkat morbiditas dan mortalitas yang tinggi, terutama di negara berkembang. Tekanan darah tinggi atau hipertensi dapat meningkatkan risiko penyakit

${ }^{*}$ Penulis Penanggungjawab 
kardiovaskuler. Menurut RISKESDAS tahun 2007 prevalensi hipertensi di Indonesia mencapai $31,7 \%{ }^{1}$ Sedangkan prevalensi hipertensi pada wanita yang memiliki berat badan berlebih dan atau obesitas meningkat sebesar $15 \%$ - 38\%, dan menjadi dua kali lipatnya pada wanita yang telah mengalami menopause. ${ }^{2}$ Peningkatan risiko hipertensi pada wanita post menopause disebabkan karena berkurangnya hormon estrogen yang menyebabkan vasokonstriksi pembuluh darah sehingga tekanan darah meningkat. ${ }^{3,4}$ Sedangkan risiko hipertensi pada wanita dengan kelebihan berat badan disebabkan karena tingginya lemak tubuh sehingga mengakibatkan kerusakan pada sistem syaraf simpatik dan aktivasi sistem reninangiotensin. ${ }^{5}$ Sementara itu, diketahui pada wanita post menopause cenderung terjadi peningkatan massa lemak tubuh. ${ }^{6}$ Hal ini dapat meningkatkan risiko hipertensi pada wanita post menopause.

Selain dipengaruhi oleh massa lemak tubuh, tekanan darah juga dipengaruhi oleh asupan, dalam penelitian ini yakni asupan zat gizi makro yang meliputi karbohidrat, protein, dan lemak. Pada penelitian randomized trial oleh OMNIHEART, dimana 3 kelompok subjek diberikan 3 intervensi diet, yakni diet karbohidrat berdasarkan pola diet DASH, diet protein, dan diet lemak tak jenuh tunggal, diketahui bahwa ketiga jenis diet dapat menurunkan tekanan darah. Penurunan tekanan darah lebih signifikan pada kelompok yang mendapat intervensi diet protein dan lemak tak jenuh tunggal. ${ }^{7}$

Penelitian INTERMAP mengenai hubungan asupan protein dengan tekanan darah yang melibatkan 4.680 pria dan wanita berusia 40-59 tahun di Cina, Jepang, Inggris, dan Amerika menunjukkan bahwa asupan protein nabati berkorelasi negatif dengan tekanan darah, akan tetapi asupan protein total pada wanita tidak berhubungan dengan tekanan darah. ${ }^{8}$ Sedangkan penelitian intervensi kelompok kasus dan kontrol yang melibatkan 60 subjek hipertensi di Australia menunjukkan bahwa sedikit substitusi makanan sumber karbohidrat seperti roti, pasta, nasi, kentang, dan sereal dengan daging merah dapat menurunkan tekanan darah. ${ }^{9}$

Dalam beberapa penelitian disebutkan bahwa mekanisme penurunan tekanan darah oleh protein disebabkan karena adanya asam amino arginin dan asam glutamat. ${ }^{8-10}$ Penelitian intervensi kepada enam pasien penderita diabetes mellitus tipe 2 dengan hipertensi ringan di Amerika menunjukkan bahwa pemberian suplementasi arginin secara oral dapat menurunkan tekanan darah. ${ }^{11}$ Sementara itu dalam penelitian INTERMAP mengenai hubungan asupan glutamat dengan tekanan darah, menunjukkan bahwa adanya hubungan negatif antara asupan asam glutamat dengan tekanan darah. ${ }^{12}$

Penelitian ini bertujuan untuk mengetahui hubungan antara asupan monosakarida, asam lemak tak jenuh ganda (PUFA), arginin, asam glutamat, dan massa lemak tubuh terhadap tekanan darah pada wanita post menopause.

\section{METODE}

Ruang lingkup penelitian adalah gizi masyarakat dengan desain cross sectional, yang dilaksanakan pada bulan Januari - Februari 2013. Data 75 responden diambil menggunakan teknik consecutive sampling dengan populasi target adalah wanita post menopause, populasi terjangkau merupakan wanita post menopause yang diambil di kelompok pengajian Yamata dan Isy Karima di kota Solo. Pemilihan tempat adalah dengan pertimbangan belum pernah dilakukan penelitian di daerah Solo, serta diketahui bahwa peserta dalam kelompok pengajian ini tidak berasal dari satu wilayah di kota Solo, dan sebagian besar peserta merupakan wanita post menopause. Protokol dan kriteria inklusi pengambilan data yakni sudah mengalami menopause selama minimal satu tahun, tidak sedang mengkonsumsi obat - obatan dan/atau terapi hormon yang dapat mempengaruhi tekanan darah selama tiga hari terakhir, tidak mengkonsumsi makanan/minuman berkafein selama satu hari terakhir, menghindari makan 4 jam sebelum dilakukan pengukuran dengan BIA, tidak merokok dan mengkonsumsi alkohol, tidak sedang dalam keadaan diet pengurangan garam, berkemih sebelum dilakukan pengambilan data, melipat lengan baju pada bagian yang akan diukur tekanan darahnya, tidak berbicara serta rileks selama dilakukan pengukuran tekanan darah. ${ }^{13}$

Variabel bebas dalam penelitian ini meliputi asupan karbohidrat monosakarida, PUFA, arginin, asam glutamat, dan massa lemak tubuh. Variabel terikat yakni tekanan darah. Data yang dikumpulkan meliputi data umum subjek, data asupan, indeks massa tubuh (IMT), massa lemak tubuh (MLT), dan tekanan darah. Data asupan diperoleh melalui wawancara dengan kuesioner Food Frequency Semi Quantitatif. Data asupan yang didapat merupakan asupan selama satu tahun terakhir yang dihitung menjadi rata - rata asupan sehari dalam satuan gram dan dikelompokan berdasarkan nilai median. Data IMT didapatkan 
melalui hasil perhitungan berat badan dibagi tinggi badan kuadrat. Berat badan diukur menggunakan timbangan digital dengan kapasitas $150 \mathrm{~kg}$ dan ketelitian $0,1 \mathrm{~kg}$ sedangkan tinggi badan diukur menggunakan microtoise dengan kapasitas $200 \mathrm{~cm}$ dan ketelitian $0,1 \mathrm{~cm}$. Pengelompokan IMT menurut WHO dikategorikan menjadi underweight $\left(<18,5 \mathrm{~kg} / \mathrm{m}^{2}\right)$, normal $\left(18,5-22,9 \mathrm{~kg} / \mathrm{m}^{2}\right)$, overweight $\left(23,0-24,9 \mathrm{~kg} / \mathrm{m}^{2}\right)$, dan obese $(\geq 25,0$ $\left.29,9 \mathrm{~kg} / \mathrm{m}^{2}\right) .{ }^{14}$ Data MLT diperoleh melalui pengukuran dengan alat Bioelectrical Impedance Analysis (BIA) Beurer tipe BG42 yang dinyatakan dalam persentase massa lemak tubuh per total berat badan. ${ }^{15}$ Pengelompokan MLT dibedakan berdasarkan usia. Untuk wanita usia 40-59 tahun, MLT dikategorikan atas normal (23-34,9\%), overfat (35-39,9\%), serta obesitas ( $\geq 40 \%)$. Untuk wanita usia 60-79 tahun, MLT juga dikategorikan atas normal (24-35,9\%), overfat (36-41,9\%), dan obesitas $(\geq 42 \%) .{ }^{16}$ Pengambilan data tekanan darah dilakukan pada pagi hari oleh tenaga terlatih dengan posisi subjek rileks dan posisi lengan sejajar jantung, dengan menggunakan Sphygnomanometer aneroid OneMed dengan ukuran cuff atau manset panjang 25-30 $\mathrm{cm}$ dan lebar $12-15 \mathrm{~cm}^{13}$ Pengukuran tekanan darah sebaiknya dilakukan pengulangan sebanyak 3 kali untuk memastikan hasil ukur. Akan tetapi peneliti hanya melakukan satu kali pengukuran. Responden dikategorikan hipertensi apabila memiliki tekanan darah sistolik $\geq 140 \mathrm{mmHg}$ dan tekanan darah diastolik >90 mmHg. ${ }^{5}$

Data yang diperoleh dianalisis secara statistik. Analisis univariat untuk mendeskripsikan data gambaran umum subjek meliputi distribusi frekuensi dan presentase. Data diuji kenormalannya dengan menggunakan uji Kolmogorov-Smirnov, diketahui data tekanan darah berdistribusi tidak normal, dan data asupan berdistribusi normal. Analisis bivariat dengan menggunakan uji korelasi rank Spearman.

\section{HASIL PENELITIAN \\ Karakteristik Subjek Penelitian}

Karakteristik subjek berdasarkan pendidikan, usia, dan tekanan darah dapat dilihat dalam tabel 1 .

Tabel 1. gambaran umum berdasarkan pendidikan, usia, dan tekanan darah subjek

\begin{tabular}{lll}
\hline Karakteristik & $\mathrm{n}$ & $\%$ \\
\hline Pendidikan & & \\
$\quad$ Dasar & 33 & 44,0 \\
Menengah & 30 & 40,0 \\
$\quad$ Tinggi & 12 & 16,0 \\
Usia & & \\
40-59 & 44 & 58,7 \\
Hipertensi & & \\
$\quad$ Sistolik & 13 & 17,3 \\
Diastolik & 28 & 37,3 \\
\hline
\end{tabular}

Sebagian besar subjek menempuh pendidikan dasar, yakni tingkat SD dan SMP $(44,0 \%)$. Subjek yang diteliti memiliki kisaran usia 48-78 tahun dengan nilai rerata \pm SD yakni $58,4 \pm 7,6$ dan sebagian besar subjek berusia kurang dari 60 tahun (58,7\%). Sebanyak 13 subjek $(17,3 \%)$ memiliki hipertensi sistolik, dan 28 subjek $(37,3 \%)$ memiliki hipertensi diastolik. Tidak seluruh subjek mengalami hipertensi, akan tetapi sebagian besar menyatakan bahwa tekanan darahnya cenderung rendah pada saat pre menopause, dan meningkat menjadi normal setelah melewati masa menopause.

Karakteristik subjek dilihat berdasarkan MLT dan IMT ditunjukkan dalam gambar 1 . 


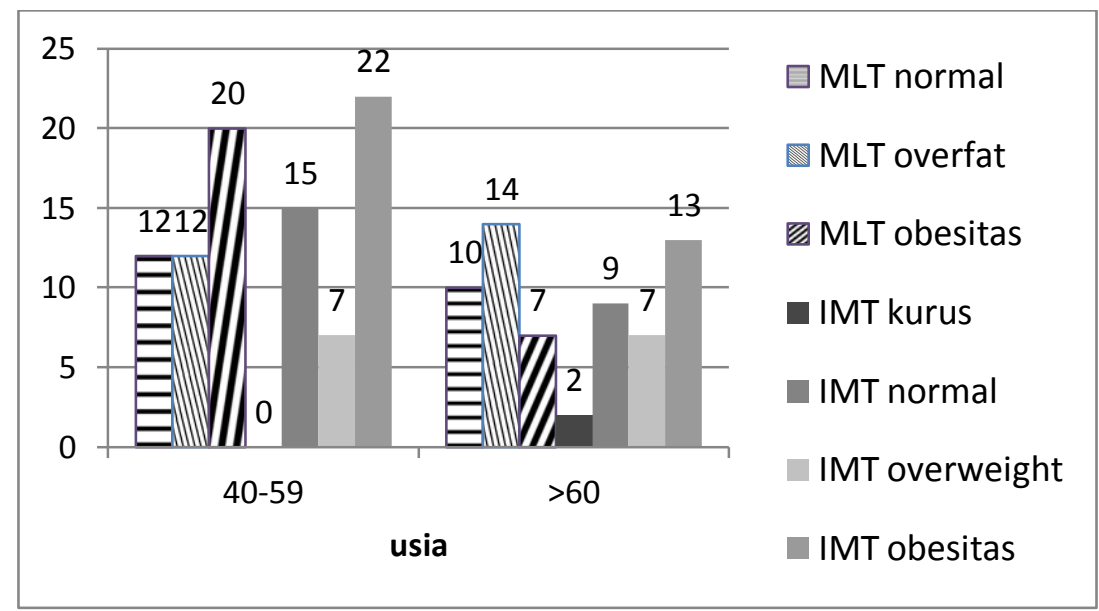

Gambar 1. Perbandingan MLT dan IMT Berdasarkan Kategori Usia

Massa lemak tubuh subjek berkisar 23,1$49 \%$ dengan rerata dan standar deviasi yakni $38,2 \pm 5,4$. Sebagian besar subjek pada kelompok usia $<60$ tahun mengalami obesitas, dan subjek pada kelompok usia $\geq 60$ tahun mengalami overfat. Sedangkan rerata dan standar deviasi IMT adalah $25,1 \pm 3,9$ dan sebagian besar subjek pada kedua kelompok usia mengalami obesitas. Sebanyak 2 subjek yang tergolong dalam IMT kurus memiliki MLT normal. Dan 41 subjek yang tergolong dalam IMT overweight dan obesitas memiliki MLT yang overfat dan obesitas pula.

\section{Asupan dan Tekanan Darah Subjek}

Karakteristik subjek dilihat berdasarkan asupan dan tekanan darah ditunjukkan dalam gambar 2.
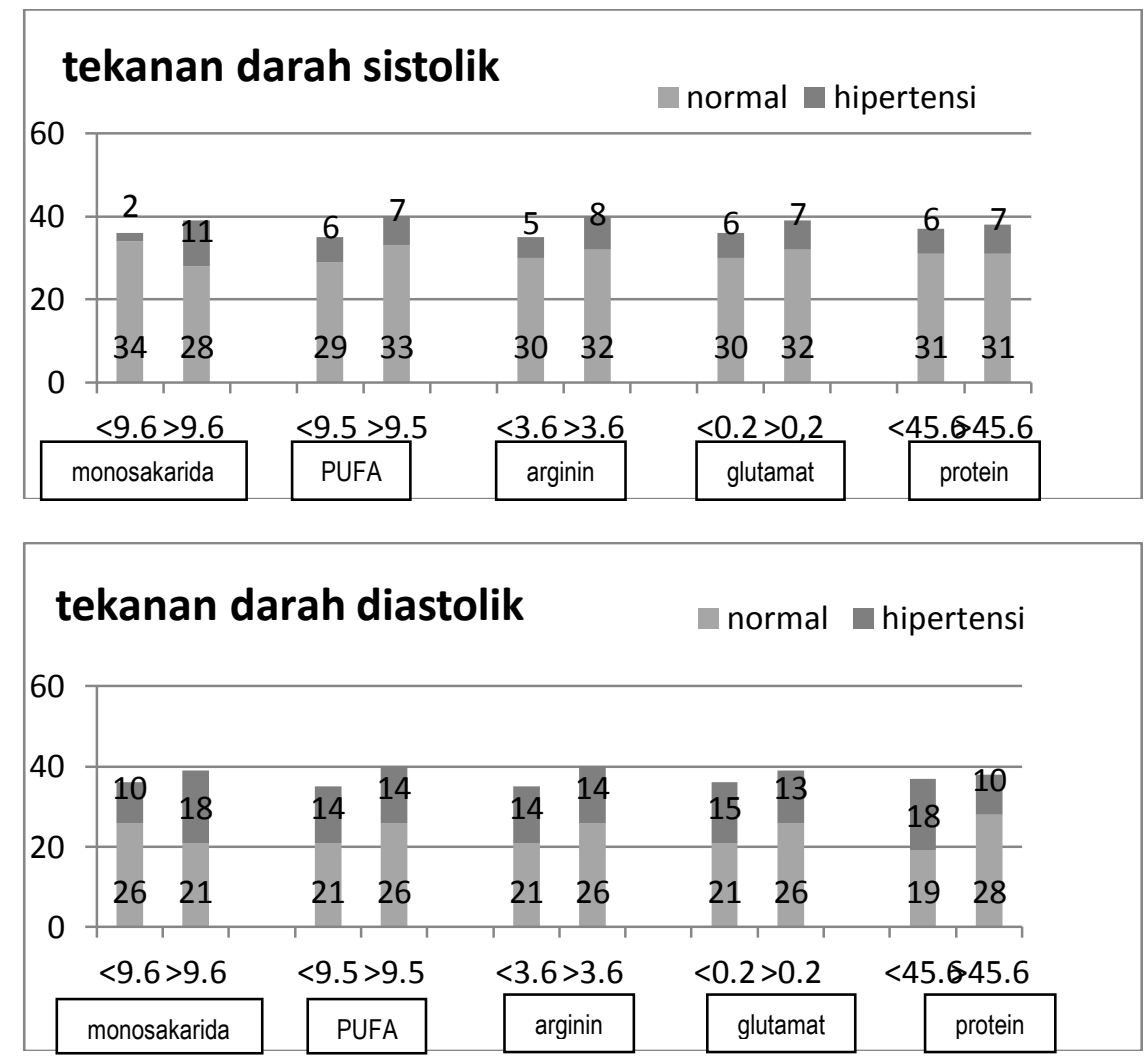

Gambar 2. gambaran umum subjek berdasarkan asupan dan tekanan darah subjek

Pengelompokkan asupan berdasarkan nilai median data. Asupan monosakarida 39 subjek
(52\%) lebih dari 9,6 gram per hari dengan rerata asupan $10 \pm 5,9$ gram. Bahan makanan sumber 
monosakarida secara dominan berasal dari buah dan sayur seperti brokoli, wortel, tomat, melon, pisang, anggur, dan alpukat.

Rerata \pm SD asupan protein total yakni $47,5 \pm 12,1$ gram. Bahan makanan sumber protein yang sering dikonsumsi meliputi telur, ikan air tawar, daging ayam, tahu, tempe, kedelai rebus, kacang tanah rebus, dan susu kedelai. Dalam wawancara penelitian diketahui tingginya konsumsi kacang — kacangan pada responden, sehingga rerata \pm SD asupan PUFA mencapai $9,8 \pm 3,8$ gram. Sementara itu, rerata asupan arginin adalah $4 \pm 1,8$ gram dan sebanyak 40 subjek $(53,3 \%)$ mengasup arginin lebih dari 3,6 gram per hari. Rerata asupan asam glutamat adalah $0,8+1,7$ gram dengan sebanyak 39 subjek (52\%) mengasup asam glutamat kurang dari 0,2 gram per hari

Tabel 2. Bahan Makanan yang Sumber Zat Gizi, di Konsumsi oleh Subjek

\begin{tabular}{|c|c|c|c|}
\hline Monosakarida & PUFA & Arginin & Asam glutamat \\
\hline Wortel $(82,7 \%)$ & Tahu (100\%) & Beras $(100 \%)$ & Susu kedelai (28\%) \\
\hline Tomat $(62,7 \%)$ & Tempe $(100 \%)$ & $\begin{array}{l}\text { Daging ayam } \\
(66,7 \%)\end{array}$ & Biskuit $(33,3 \%)$ \\
\hline Brokoli $(29,3 \%)$ & $\begin{array}{l}\text { Minyak sawit } \\
(100 \%)\end{array}$ & $\begin{array}{l}\text { Daging sapi } \\
(10,7 \%)\end{array}$ & Roti gandum (4\%) \\
\hline Melon $(26,7 \%)$ & Telur $(53,3 \%)$ & $\begin{array}{l}\text { Ikan bandeng dan } \\
\text { lele }(30,7 \%)\end{array}$ & \\
\hline \multirow[t]{2}{*}{ Anggur (12\%) } & Kedelai (24\%) & $\begin{array}{l}\text { Hidangan laut } \\
(45,3 \%)\end{array}$ & \\
\hline & $\begin{array}{l}\text { Kacang tanah } \\
(22,7 \%)\end{array}$ & $\begin{array}{l}\text { Ikan air tawar } \\
(5,3 \%) \\
\text { Jerohan }(13,3 \%) \\
\text { Sosis }(18,7 \%)\end{array}$ & \\
\hline
\end{tabular}

Hidangan laut yang dikonsumsi meliputi ikan tongkol, kakap, tengiri, ikan asin, dan udang. Sedangkan jenis ikan air tawar yang dikonsumsi yakni ikan kembung, mujahir, dan ikan mas. Sementara itu jenis jerohan yang sering dikonsumsi meliputi hati dan ampela yang berasal dari unggas.

Hubungan Asupan Monosakarida, PUFA, Arginin, dan Asam Glutamat dengan Tekanan Darah Sistolik dan Diastolik

Uji korelasi massa lemak tubuh dengan tekanan darah, menunjukkan bahwa terdapat korelasi positif yang bermakna namun dengan kekuatan korelasi yang lemah antara tekanan darah sistolik $(r=0,267 ; p=0,020) \quad$ [gambar 1.] dan dengan tekanan darah diastolik $(r=0,256$; $p=0,022$ ) [gambar 2.]. Hasil yang serupa ditunjukkan pada uji hubungan asupan monosakarida dengan tekanan darah sistolik $(p=0,020 ; \quad r=0,268)$ yang ditunjukkan dalam gambar 3, dan dengan tekanan darah diastolik $(p=0,011 ; \quad r=0,291)$ yang ditunjukkan dalam gambar 4. Hal ini menunjukkan bahwa semakin tinggi massa lemak tubuh dan asupan monosakarida, maka tekanan darah akan semakin tinggi.

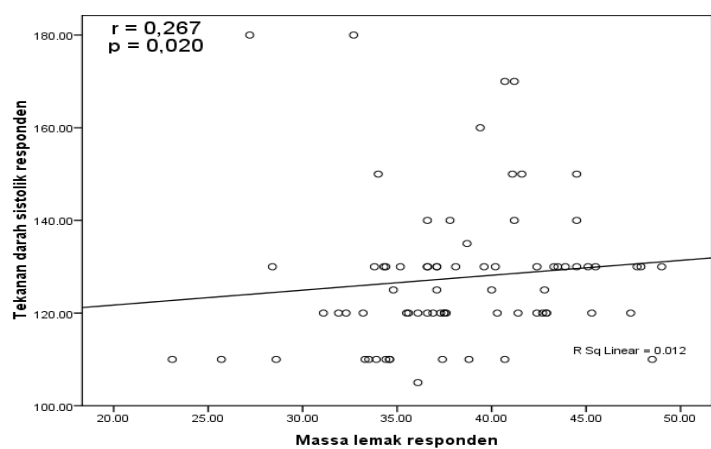

Gambar 3. Diagram Tebar Hubungan Massa Lemak Tubuh dengan Tekanan Darah Sistolik $(n=75)$

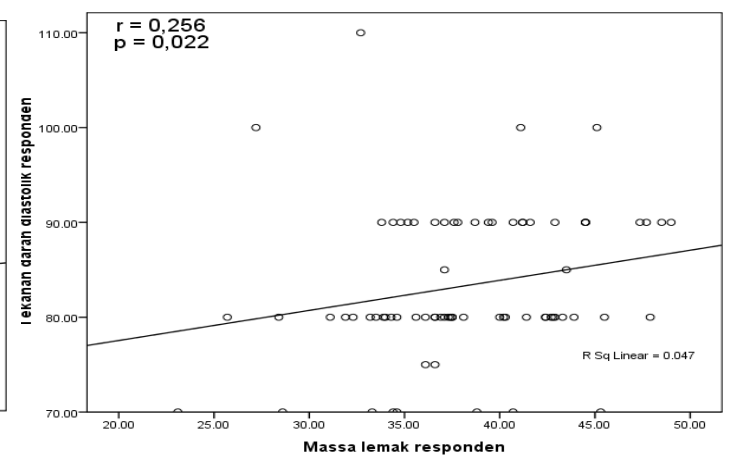

Gambar 4. Diagram Tebar Hubungan Massa Lemak Tubuh dengan Tekanan Darah Diastolik $(n=75)$ 


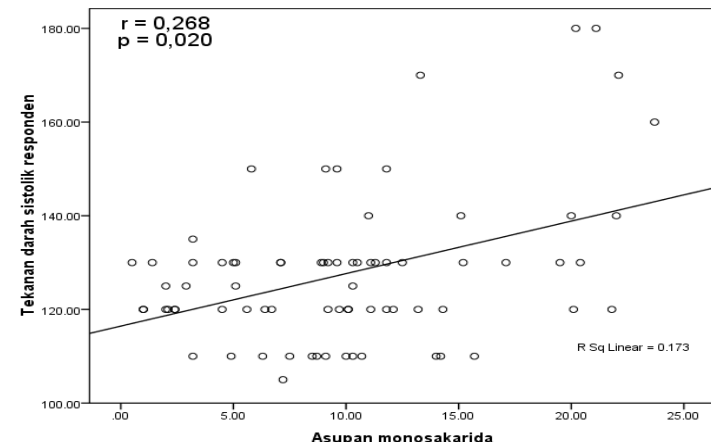

Gambar 5. Diagram Tebar Hubungan Asupan Monosakarida dengan Tekanan Darah Sistolik ( $\mathrm{n}=75)$

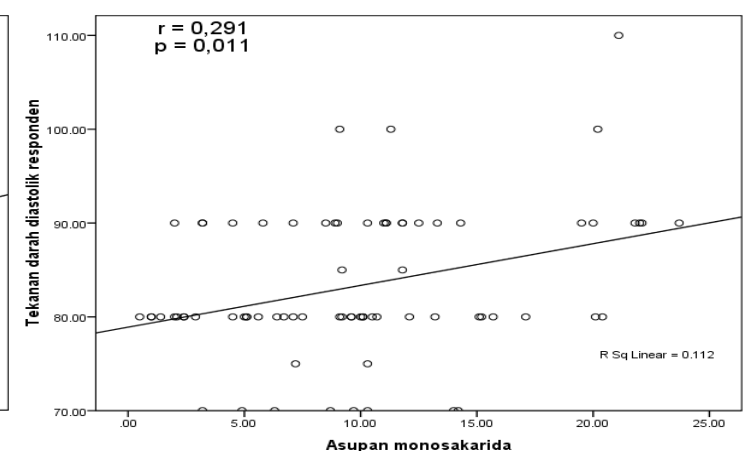

Gambar 6. Diagram Tebar Hubungan Asupan Monosakarida dengan Tekanan Darah Diastolik $(n=75)$

Tabel 3. Hubungan Asupan Asam Lemak Tak Jenuh Ganda, Arginin, dan Asam Glutamat dengan Tekanan Darah Sistolik dan Diastolik

\begin{tabular}{lcccc}
\hline \multirow{2}{*}{ Variabel } & \multicolumn{2}{c}{ Tekanan darah sistolik } & \multicolumn{2}{c}{ Tekanan darah diastolik } \\
\cline { 2 - 5 } & $\mathrm{r}$ & $\mathrm{p}$ & $\mathrm{r}$ & $\mathrm{p}$ \\
\hline Lemak tak jenuh ganda & $-0,206$ & 0,076 & $-0,093$ & 0,426 \\
Arginin & 0,086 & 0,463 & 0,040 & 0,732 \\
Asam glutamat & 0,040 & 0,734 & 0,040 & 0,734 \\
\hline
\end{tabular}

Pada analisis korelasi asupan PUFA dengan tekanan darah yang ditunjukkan pada tabel 4, didapatkan hasil bahwa semakin tinggi asupan PUFA maka tekanan darah sistolik $(r=-0,206$; $p=0,076)$ dan diastolik $(r=-0,093 ; p=0,426)$ akan semakin rendah. Akan tetapi pada analisis korelasi asupan asam lemak arginin dan asam glutamat yang ditunjukkan pada tabel 4 menunjukkan bahwa semakin tinggi asupan arginin $(r=0,086 p=0,463$; $r=0,040 p=0,732)$ dan asam glutamat $(r=0,040$ $p=0,734 ; r=0,040 p=0,734)$ maka tekanan darah sistolik dan diastolik juga semakin tinggi. Hubungan asupan PUFA, arginin, dan asam glutamat dengan tekanan darah memiliki kekuatan korelasi yang lemah serta tidak bermakna sebab memiliki nilai $\mathrm{p}>0,05$.

\section{PEMBAHASAN}

Dalam penelitian ini terdapat 13 subjek hipertensi sistolik dengan rentang nilai tekanan darah $140-180 \mathrm{mmHg}$, dan 28 subjek hipertensi diastolik dengan rentang tekanan darah 90-110 mmHg. Pengamatan mendalam menunjukkan bahwa hipertensi sistolik dialami oleh 5 subjek berusia 40-59 tahun dan 8 subjek berusia lebih dari 59 tahun, dengan 4 subjek memiliki tekanan darah lebih dari $170 \mathrm{mmHg}$. Sementara itu, terdapat 18 subjek berusia $40-59$ tahun dan 10 subjek berusia lebih dari 59 tahun yang memiliki hipertensi diastolik, dimana 4 subjek diantaranya memiliki nilai tekanan darah diastolik lebih dari
$100 \mathrm{mmHg}$. Sedikitnya prevalensi hipertensi yang didapatkan diduga karena adanya bias dalam pengambilan data tekanan darah, yakni tidak dilakukan pengulangan pengukuran. Hal ini disebabkan karena terbatasnya waktu, sehingga beberapa subjek enggan melakukan pengulangan pengukuran tekanan darah.

Tidak seluruh responden dalam penelitian ini mengalami hipertensi, akan tetapi sebagian besar responden menyatakan bahwa tekanan darahnya meningkat setelah mereka mengalami menopause. Sebelum mengalami menopause, tekanan darah wanita cenderung lebih rendah dibandingkan dengan pria. ${ }^{4,17}$ Pada kondisi post menopause, produksi hormon estrogen akan berkurang, dimana estrogen berperan sebagai vasodilator dengan cara meningkatkan bioavaibilitas nitric oxide (NO) dan menghambat sistem rennin - angiotensin-aldosteron. ${ }^{4}$ Peningkatan tekanan darah sistolik yang terjadi pada wanita post menopause yakni sebesar $4-5$ mmHg. ${ }^{18}$

Penentuan status gizi subjek dilakukan dengan menggunakan penilaian massa lemak tubuh, sebab pada wanita post menopause pada umumnya terjadi perubahan komposisi tubuh, termasuk penyusutan massa otot dan peningkatan massa lemak tubuh. ${ }^{19}$ Dalam penelitian ini, terdapat 6 subjek overfat dan 4 subjek obesitas yang memiliki hipertensi sistolik, serta 12 subjek overfat dan 11 subjek obesitas yang memiliki 
hipertensi diastolik. Disamping itu, hipertensi sistolik juga dialami oleh 3 subjek dengan MLT normal, dan hipertensi diastolik dimiliki oleh 5 subjek dengan MLT normal. Pada pengelompokan status gizi dan hipertensi berdasarkan usia, diketahui bahwa hipertensi sistolik dialami oleh 1 subjek overfat dan 3 subjek obesitas yang berusia $40-59$ tahun, serta 5 subjek overfat dan 1 subjek obesitas yang berusia lebih dari 59 tahun. Sementara itu hipertensi diastolik dialami oleh 7 subjek overfat dan 8 subjek obesitas yang berusia 40-59 tahun, serta 5 subjek overfat dan 3 subjek obesitas yang berusia lebih dari 59 tahun. Dapat disimpulkan bahwa berdasarkan kelompok usia, insiden hipertensi meningkat pada subjek yang overfat dan berusia lebih dari 59 tahun. Akan tetapi perbedaan insiden hipertensi lebih menonjol antar kelompok overfat dan obesitas pada subjek dengan usia 40-59 tahun. Hal ini sesuai dengan penelitian Brown, dimana dinyatakan bahwa peningkatan prevalensi hipertensi pada wanita berlangsung seiring dengan bertambahnya usia pada berbagai tingkatan status gizi, akan tetapi korelasi hipertensi dengan status gizi lebih menonjol pada wanita dengan kelompok usia muda. ${ }^{2}$

Pada subjek yang berusia 40-59 tahun, diketahui 9 subjek dengan IMT overweight dan obesitas memiliki kategori MLT overfat, dan 16 subjek dengan IMT obesitas memiliki MLT yang obesitas pula. Sementara itu terdapat 6 subjek berusia lebih dari 59 tahun yang memiliki MLT dan IMT yang obesitas. Peningkatan massa lemak tubuh pada wanita post menopause disebabkan karena berkurangnya kadar estrogen dalam tubuh yang kemudian menurunkan sensitifitas hormon leptin dan meningkatkan asupan makanan. ${ }^{20}$ Peningkatan hormon leptin berkaitan dengan penurunan sensitifitas insulin dan aktifitas fisik pada orang tua. ${ }^{19,21}$ Leptin dapat mempengaruhi tekanan darah melalui aktivasi sistem syaraf simpatetik di hipotalamus. Obesitas dapat meningkatkan tekanan darah melalui mekanisme penyempitan pembuluh darah akibat penumpukan lemak, gangguan fungsi ginjal, serta adanya retensi cairan dalam tubuh. ${ }^{22,23}$ Hal ini menjelaskan hasil dalam penelitian ini, yakni adanya korelasi yang bermakna antara peningkatan massa lemak tubuh dan peningkatan tekanan darah sistolik $(r=0,267$; $p=0,020)$ [gambar 1.] dan diastolik $(r=0,256$; $p=0,022$ ) [gambar 2.].

Rerata asupan monosakarida subjek adalah 9,9 gram. Ditemukan bahwa pada subjek yang mengkonsumsi monosakarida lebih dari 9,6 gram, hipertensi sistolik dialami oleh 11 subjek, dan hipertensi diastolik dialami oleh 18 subjek. Akan tetapi ditemukan pula bahwa sebanyak 2 subjek yang mengkonsumsi monosakarida kurang dari rerata mengalami hipertensi sistolik, dan 10 subjek mengalami hipertensi diastolik. Sementara itu, rerata asupan PUFA subjek yakni 9,8 gram per hari. Sebanyak 6 subjek yang mengkonsumsi PUFA kurang dari 9,5 gram memiliki hipertensi sistolik, dan 14 subjek memiliki hipertensi diastolik. Akan tetapi terdapat pula 7 subjek yang mengkonsumsi PUFA lebih dari 9,5 gram memiliki hipertensi sistolik, dan 14 subjek memiliki hipertensi diastolik. Adanya insiden hipertensi pada subjek yang mengkonsumsi monosakarida kurang dari 9,6 gram dan pada subjek yang mengkonsumsi PUFA lebih dari 9,5 gram diduga karena adanya perbedaan respon dan sekresi insulin antar individu, ${ }^{24}$ dimana insulin berperan dalam metabolisme karbohidrat dan lemak. Selain itu, adanya riwayat hipertensi pada subjek dan asupan zat gizi lain dapat mempengaruhi tekanan darah, sehingga peningkatan tekanan darah tidak hanya dipengaruhi oleh asupan monosakarida dan PUFA. ${ }^{7}$

Dalam penelitian ini, asupan monosakarida berkorelasi positif secara signifikan dengan peningkatan tekanan darah sistolik $(r=0,268$; $p=0,020)$ dan diastolik $(r=0,291 ; p=0,011)$. Hasil penelitian ini sesuai dengan penelitian lain yang menunjukkan adanya hubungan positif antara asupan minuman yang mengandung pemanis gula dengan peningkatan tekanan darah. Peningkatan asupan minuman berpemanis gula berkorelasi terbalik dengan asupan serat dan protein nabati. ${ }^{25}$ Sementara itu, pada penelitian ini didapatkan pula bahwa asupan $P U F A$ berkorelasi negatif yang tidak bermakna secara statistik ( $r=-0,206 p=0,076$; $r=-$ $0,093 p=0,426$ ). Hal ini sesuai dengan penelitian yang menyatakan bahwa PUFA yang terdiri atas asam linoleat dan linolenat berkorelasi negatif dengan tekanan darah. ${ }^{26,27,28}$ Monosakarida akan meningkatkan glukosa darah sesaat setelah dikonsumsi. Meningkatnya glukosa darah akan meningkatkan heart rate dimana jantung memompa darah lebih cepat sehingga meningkatkan cardiac output dan terjadi peningkatan tekanan darah. ${ }^{29}$ Selain itu, asupan makanan tinggi PUFA akan menurunkan LDL darah, dimana penurunan LDL juga akan memperkecil risiko peningkatan tekanan darah oleh penumpukan kolesterol. ${ }^{26,30}$ Selain itu PUFA yang terdiri atas omega 3 dan omega 6 dapat mempengaruhi tekanan darah dengan meningkatkan produksi prostaglandin di ginjal dan 
jaringan lain, dimana prostaglandin berperan sebagai vasodilator. ${ }^{27,28}$

Bahan makanan yang diketahui merupakan sumber asupan PUFA meliputi bahan makanan mengandung minyak yang berasal dari nabati, seperti biji bunga matahari, minyak kedelai, dan minyak kacang. ${ }^{31}$ Dalam penelitian ini, diketahui subjek banyak mengasup produk kedelai, dan kacang tanah. Sementara itu, bahan makanan sumber monosakarida yang sering dikonsumsi adalah sayuran dan buah-buahan, meliputi wortel, tomat, melon, dan brokoli. Akan tetapi, studi mengenai hubungan konsumsi sayuran dan buah-buahan dengan tekanan darah dan risiko penyakit jantung koroner menunjukkan bahwa asupan sayuran dan buah-buahan menurunkan tekanan darah pada subjek dengan hipertensi dan risiko kejadian penyakit jantung koroner. ${ }^{32} \mathrm{Hal}$ ini disebabkan karena pada individu yang mengkonsumsi tinggi sayuran dan buah-buahan cenderung memiliki asupan serat dan antioksidan yang tinggi, serta rendah lemak jenuh. ${ }^{33,34}$ Selain itu, pada sebuah penelitian dimana subjek yang menjalani diet karbohidrat berdasarkan Dietary Approaches to Stop Hypertension (DASH) mengalami penurunan tekanan darah secara signifikan. ${ }^{7}$ Pola diet DASH yakni meningkatkan konsumsi sayuran, buah - buahan, dan produk susu rendah lemak, mengkonsumsi whole grains, kacang - kacangan, unggas dan ikan, serta mengurangi asupan daging merah, mentega, dan pemanis. ${ }^{35,36}$ Konsumsi tinggi protein, serat, dan rendah starch berperan dalam menurunkan tekanan darah. ${ }^{9}$ Akan tetapi mekanisme bagaimana asupan monosakarida pada sayur dan buah-buahan terhadap tekanan darah masih belum jelas.

Asupan protein responden yakni 47,5+12,1 gram per hari, dengan asupan protein nabati $24,6 \pm 7,2$ gram per hari dan protein hewani $22,9 \pm 9,5$ gram per hari. Rata - rata asupan protein nabati lebih tinggi, sebab subjek terbiasa mengkonsumsi kedelai rebus, kacang tanah rebus, tahu serta tempe. Mekanisme penurunan tekanan darah oleh protein disebabkan karena adanya peran asam amino dalam protein. ${ }^{8,9,37}$ Pada subjek yang mengkonsumsi tinggi protein hewani mamiliki asupan arginin yang lebih tinggi, sedangkan asupan asam glutamat lebih tinggi pada subjek yang mengkonsumsi tinggi protein nabati. ${ }^{8}$ Arginin dapat meningkatkan bioavaibilitas nitric oxide (NO) yang berperan dalam mekanisme vasodilatasi pembuluh darah. Selain itu regulasi arginin juga berperan dalam pelepasan hormon insulin dari sel beta di pankreas. Adanya hormon insulin menekan pembentukan angiotensinogen oleh angiotensin II sehingga tidak terjadi vasokonstriksi. ${ }^{38}$ Akan tetapi dalam penelitian ini didapatkan hasil bahwa asupan arginin tidak berkorelasi dengan tekanan darah sistolik $(r=0,086 ; \quad p=0,463)$ dan diastolik $(r=0,040 ; \quad p=0,732)$. Hasil penelitian ini berkebalikan dengan penelitian intervensi terhadap enam orang pasien hipertensi dengan diabetes mellitus tipe 2 di Amerika, dimana suplementasi arginin secara oral dapat menurunkan tekanan darah subjek. ${ }^{11}$ Ketidaksesuaian dalam penelitian ini mungkin disebabkan karena tertutupnya dampak peningkatan NO oleh stress oksidatif dan gangguan sistem rennin-angiotensinaldosteron ${ }^{37,38}$ Selain itu efek penurunan tekanan darah tidak dipengaruhi oleh asam amino arginin itu sendiri, melainkan karena adanya asupan zat gizi lain yang mempengaruhi, seperti kalsium, magnesium, dan kalium ${ }^{39}$

Sementara itu, asupan glutamat juga dapat mempengaruhi tekanan darah. Dalam penelitian INTERMAP yang melibatkan 4.680 pria dan wanita berusia 44-57 tahun, diketahui adanya hubungan negatif antara asupan asam glutamat dengan tekanan darah. Peningkatan asupan asam glutamat berkorelasi dengan penurunan $1,5-2,5$ $\mathrm{mmHg}$ tekanan darah sistolik dan $1,0-1,6 \mathrm{mmHg}$ tekanan darah diastolik. ${ }^{12}$ Akan tetapi hasil dalam penelitian ini ditemukan bahwa asupan asam glutamat tidak berkorelasi dengan tekanan darah sistolik $(r=0,040 ; \quad p=0,734)$ dan diastolik $(r=0,040 ; \quad p=0,732)$. Hal ini kemungkinan disebabkan karena tubuh mengabsorbsi asam glutamat dalam bentuk ikatannya bersama folat, yakni asam pteroilglutamat. Folat berikatan dengan glutamat supaya dapat disintesis oleh DNA. Folat diketahui dapat meningkatkan homosistein tubuh, dimana diduga peningkatan homosistein tubuh dapat mempengaruhi tekanan darah dan melindungi dari risiko penyakit jantung. ${ }^{40}$ Sementara itu mekanisme folat terhadap tekanan darah sendiri masih belum diketahui.

Bahan makanan sumber arginin yang sering dikonsumsi adalah daging ayam, daging sapi, jerohan, sosis, dan ikan yang meliputi ikan air tawar, asin, dan tambak. Sedangkan bahan makanan sumber asupan asam glutamat yang sering dikonsumsi adalah susu kedelai, biskuit, roti gandum, oatmeal, dan sayuran seperti brokoli, dan wortel. Sumber protein nabati mengandung asam amino glutamat, sistin, prolin, fenilalanin, dan serin yang lebih tinggi dibanding sumber protein hewani. Sebaliknya, sumber protein hewani cenderung mengandung arginin yang lebih tinggi 
dibanding protein nabati. ${ }^{8,12}$ Selain itu, pada sumber protein kedelai mengandung isoflavone, dimana isoflavone diketahui dapat mengurangi frekuensi gejala menopause dan pengeroposan tulang. ${ }^{41,42}$ Akan tetapi masih terdapat kontroversi pada hubungan asupan isoflavone dengan tekanan darah. $^{43,44}$

\section{KESIMPULAN}

Ada hubungan bermakna yang lemah antara massa lemak tubuh dan asupan monosakarida dengan tekanan darah. Terdapat hubungan yang lemah dan tidak bermakna antara asupan $P U F A$, asam asam amino arginin, dan asam glutamat dengan tekanan darah.

\section{DAFTAR PUSTAKA}

1. Departemen Kesehatan RI. Laporan Riset Kesehatan Dasar (RISKESDAS) 2007 Propinsi Jawa Tengah. Jakarta; 2008.

2. Clarice Brown, et al. Body Mass Index and the Prevalence of Hypertension and Dyslipidemia. Obes Res. 2000; 8: 605 - 619 .

3. Baziad A. Menopause Dan Andropause. Jakarta: Yayasan Bina Pustaka Sarwono Prawirodihardjo; 2003. p. 112-16.

4. Matthias Barton, Matthias Meyer. Postmenopausal Hypertension: Mechanism and Therapy. Journal of American Heart Association. 2009; 54: 11-18.

5. Janice Raymond, Sarah Couch. Medical Nutrition Therapy for Cardiovascular Disease. In : Krause's Food And Nutrition Therapy $13^{\text {th }}$ Edition. Philadelphia: Saunders; 2012. p.742-780.

6. Rofles SR, Pinna K, Whitney E. understanding Normal and Clinical Nutrition, $8^{\text {th }}$ ed. Belmont: Thompson Wadsworth; 2009. p.260-263.

7. Lawrence Appel, et al. Effects of Protein, Monounsaturated Fat, and Carbohydrate Intake on Blood Pressure and Serum Lipids: Results of The Omniheart Randomized Trial. JAMA. 2005; 294 : 2455-64.

8. Paul Elliott, et al. Association Between Protein Intake And Blood Pressure, The INTERMAP Study. Arch Intern Med 2006, Jan 9, (166): 79-87.

9. Jonathan Hodgson, Valerie Burke, Lawrence J Beilin, Ian B Puddey. Partial Substitution of Carbohydrate Intake with Protein Intake From Lean Red Meat Lowers Blood Pressure In Hypertensive Person. AmJ ClinNutr 2006;83:780-7.

10. McCullough M, Lin PH. Nutrition, diet, and Hypertension. In: Coulston AM, Rock CK, Monsen ER (ed). Nutrition in the Prevention and Treatment of Disease. San Diego: academic Press; 2001. p.584.

11. Huynh NT, Tayek JA. Oral Arginine Reduces Systemic Blood Pressure In Type 2 Diabetes: It's Potential Role in Nitric Oxide Generation. Journal of American College of Nutrition. 2002, 21 (5): $422-427$.

12. Jeremiah Stamler, et al. Glutamic Acid, the Main Dietary Amino Acid, and Blood Pressure. The INTERMAP Study. Journal of American Heart Association. 2009 (120). p. 221-8.

13. Lynn Bickley, Peter Szilagyi. Bates' Guide to Physical Examination and History Taking $10^{\text {th }}$ edition. Lippincott Williams \& Wilkins. 2009.

14. WHO/IOTF/IASO. The Asia-Pacific perspective: Redefining Obesity and its treatment. Hong Kong: World Health Organization, International Obesity Task Force, International Association for the Study of Obesity. 2000.

15. Melvin HW. Nutrition for Health, Fitness, And Sport $8^{\text {th }}$ Edition. Mc.Graw-Hill. 2007. p.370372.

16. Sakamoto $\mathrm{Y}$ et al. comparison of the WHO BMIclassification and body composition in ethnic group. $24^{\text {th }}$ Japan Society for the study of obesity 2003

17. Giuseppe MCR, Cristiana Vitale, Massimo Fini. Hypertension in Postmenopausal Women. [serial online] 2006. Available from: URL: www.touchbriefings.com/pdf/1882/Rosano.pdf

18. Karjalainen A. Effect of Estrogen Replacement Therapy on Metabolic Risk Factors for Ardiovascular Disease in Hysterestomized Postmenopausal Women [dissertasion]. Oulu: Oulu Univ.; 2003.

19. Rofles SR, Pinna K, Whitney E. understanding Normal and Clinical Nutrition, $8^{\text {th }}$ ed. Belmont: Thompson Wadsworth; 2009. p.566

20. Ainslie DA, Morris MJ, Wittert G, Turnbull H, Proietto J, Thornburn AW. Estrogen Deficiency Causes Central Leptin Insensitivity and Increased Hypothalamic Neuropeptide Y. Intl Journal Of Obesity 2001; 25: $1680-88$

21. Faria AN, Filho SSR, Ferreira SRG, Zanella MT. impact of visceral fat on blood pressure and insulin sensitivity in hypertensive obese women. Journal of obesity, December 2002, 10 (12): 1203-06.

22. Rahmouni K, Correia MLG, Haynes WG, Mark AL. Obesity-Associated Hypertension: New Insights Into Mechanism. Hypertension Journal of American Heart Association. 2005; 45: 9-14.

23. Rofles SR, Pinna K, Whitney E. understanding Normal and Clinical Nutrition, $8^{\text {th }}$ ed. Belmont: Thompson Wadsworth; 2009. p.858

24. Rofles SR, Pinna K, Whitney E. understanding Normal and Clinical Nutrition, $8^{\text {th }}$ ed. Belmont: Thompson Wadsworth; 2009. p.133-6.

25. Brown IJ. Sugar-Sweetened Beverage, Sugar Intake of Individuals, And Their Blood Pressure: International Study Of Macro/Micronutrients And Blood Pressure. Hypertension Journal of American Heart Association. February 2011; 57: 695-701.

26. De Rosa ML. Can Purified Omega-3 Polyunsaturated Fatty Acid Supplementation Act 
Blood Pressure Levels in Untreated Normal-High Blood Pressure Subjects With Hypertriglyceridemia. Journal of Pharmacology and Pharmacy 2012; 2: 234-9.

27. Ueshima H, et al. Food Omega-3 Fatty Acid Intake of Individuals (Total, Linolenic Acid, Long Chain) And Their Blood Pressure: INTERMAP Study. Hypertension 2007; 50: 313-319.

28. Miura K, et al. Relationship of Dietary Linoleic Acid To Blood Pressure: INTERMAP Study. Hypertension 2008; 52: 408-414.

29. Clive MB, Abdul GD, Gayathri Y, Montani JP. Fructose Ingestion Acutely Elevates Blood Pressure in Healthy Young Human. Am J Physiol Regul Integr Comp Physiol 2008, 294: R730_R737

30. Adkins Y, Darshan SK. Mechanism Underlying the Cardioprotective Effects of Omega-3 Polyunsaturated Fatty Acids. J Nut Bio 2010, 21: 781-792

31. Rofles SR, Pinna K, Whitney E. understanding Normal and Clinical Nutrition, $8^{\text {th }}$ ed. Belmont: Thompson Wadsworth; 2009. p.141.

32. Alonso A, Fuente C, Martin A, Irala J, Martinez A, Angel M. Fruit And Vegetable Consumption is Inversely Associated with Blood Pressure in Mediterranean Population With a High VegetableFat Intake: The Seguimiento Unversidad De Navarra (SUN) Study. British Journal of Nutr 2004; 92: $311-319$.

33. Dauchet L, Amouyel P, Hercberg S, Dallongeville J. Fruit and Vegetable Consumption and Risk Of Coronary Heart Disease: A Meta-Analysis Of Cohort Studies. J Nutr 2006; 136: 2588-2593.

34. Nakamura K, Nagata C, Oba S, Takatsuka N, Shimizu H. Fruit and Vegetable Intake and Mortality from Cardiovascular Disease are Inversely Associated in Japanese Women but Not in Men. J Nutr 2008; 138: 1129-1134.
35. Rofles SR, Pinna K, Whitney E. understanding Normal and Clinical Nutrition, $8^{\text {th }}$ ed. Belmont: Thompson Wadsworth; 2009. p.411

36. Janice Raymond, Sarah Couch. Medical Nutrition Therapy for Cardiovascular Disease. In: Krause's Food And Nutrition Therapy $13^{\text {th }}$ Edition. Philadelphia: Saunders; 2012. p.742-780.

37. Vasdev S, Stuckles J. Antihypertensive Effects of Dietary Protein and its Mechanism. Int J Angiol 2010; 19 (1): 7-20.

38. Vasdev S, Gill V. Antihypertensive Effect Of Arginine. Int J Angiol 2008; 17 (1): 7-22.

39. Marji McCullough, Pao Hwalin. Nutrition, Diet, and Hypertension. In: Ann Coulston, Cheryll Rock, Elaine Monsen (ed). Nutrition in the Prevention and Treatment of Disease. $1^{\text {st }}$ ed. California - Academic Press. 2001. p.310

40. Rofles SR, Pinna K, Whitney E. understanding Normal and Clinical Nutrition, $8^{\text {th }}$ ed. Belmont: Thompson Wadsworth; 2009. p.199, 338

41. Taku K, Melby MK, Kronenberg F, Kurzer MS, Messina M. Extracted or Synthesized Soybean Isoflavones Reduce Menopausal Hot Flash Frequency And Severity: Systematic Review And Meta Analysis Of Randomized Controlled Trials. Menopause 2012; Jul 19 (7): 776-90.

42. Ma DF, Qin LQ, Wan PY, Katoh R,. Soy Isoflavone Intake Inhibit Bone Resoption And Stimulates Bone Formation In Menopausal Women: Meta Analysis Of Randomized Controlled Trils. Eur J Clin Nutr 2008; 62 (2): 155-61.

43. Taku K, Et Al. Effects of Isoflavon Extract Supplements On Blood Pressure in Adult Humans: Systematic Review and Meta Analysis Of Randomized Placebo Controlled Trials. J Hypertens 2010; 28 (10): 1971-82.

44. Liu XX, Et Al. Effect of Soy Isoflavns on Blood Pressure: A Meta Analysis Of Randomized Controlled Trials. Nutr Metab Cardiovac Dis 2012; 22 (6): $463-70$. 